\title{
In-vitro penetration of pig oocytes matured in culture by frozen-thawed ejaculated spermatozoa
}

\author{
W. H. Wang, K. Niwa* and K. Okuda \\ Division of Animal Science, Faculty of Agriculture, Okayama University, Okayama 700, Japan
}

\begin{abstract}
Summary. Pig oocytes matured in culture were inseminated with frozen-thawed ejaculated spermatozoa without preincubation in modified tissue culture medium (TCM) 199. High penetration rates (85-89\%) and increased incidence of polyspermy were obtained at $25-100 \times 10^{6}$ spermatozoa $/ \mathrm{ml}$. Wide variation in penetration rates $(16-89 \%)$ was observed in oocytes inseminated in medium containing $5 \mathrm{~mm}$ caffeine and at $25-50 \times 10^{6}$ spermatozoa $/ \mathrm{ml}$ obtained from 6 boars, regardless of sperm motility. At $25-50 \times 10^{6}$ spermatozoa $/ \mathrm{ml}$, penetration rates of oocytes were dependent upon the concentration of caffeine in the medium: there was no penetration without caffeine, but penetration was highest $(89 \%)$ with $5 \mathrm{~mm}$ caffeine. None of the oocytes was penetrated in the medium supplemented with heparin at $5-40 \mu \mathrm{g} / \mathrm{ml}$. When heparin was included in the medium with $5 \mathrm{~mm}$ caffeine, it inhibited the efficacy of caffeine to promote sperm penetration of oocytes.
\end{abstract}

Keywords: in-vitro fertilization; oocyte; pig; frozen ejaculated sperm

\section{Introduction}

Successful in-vitro fertilization of pig oocytes matured in vivo or in vitro by fresh ejaculated or epididymal spermatozoa has been reported (Iritani et al., 1978; Nagai et al., 1984, 1990; Cheng, 1985; Hamano \& Toyoda, 1986; Yoshida, 1987; Naito et al., 1988; Hamano et al., 1989; Mattioli et al., 1989; Yoshida et al., 1990). Nagai et al. (1988) have reported that pig oocytes matured in vivo and in vitro can be penetrated in vitro by frozen epididymal spermatozoa. Repeated use of spermatozoa with the same characteristics for in-vitro fertilization would be a great advantage for fundamental research on fertilization mechanisms. Epididymal spermatozoa are usually obtained after boars have been killed; it is therefore not possible to use spermatozoa collected repeatedly from the same boar. This problem would be solved if techniques for fertilizing pig oocytes in vitro by frozen ejaculated spermatozoa were developed. The present study was designed to develop such techniques.

\section{Materials and Methods}

\section{Culture medium}

The basic medium, designated TCM-199B, for the manipulation of spermatozoa and oocytes was TCM-199 (with Earle's salts, Gibco Lab., USA) supplemented with $3.05 \mathrm{~mm}$ D-glucose, $2.92 \mathrm{~mm}$ calcium lactate, $0.91 \mathrm{~mm}$ sodium pyruvate, $75 \mu \mathrm{g}$ potassium penicillin $\mathrm{G} / \mathrm{ml}, 50 \mu \mathrm{g}$ streptomycin sulphate $/ \mathrm{ml}$ and $10 \%$ (v/v) heated fetal calf serum (FCS). This medium was essentially the same as that described by Cheng (1985), except that FCS was added at $10 \%$ rather than $12 \%$ and that penicillin and streptomycin, rather than dibekacin, were used as the antibiotics.

${ }^{*}$ Reprint requests. 


\section{Culture of follicular oocytes}

Ovaries were collected from maturing gilts at a local slaughterhouse and returned to the laboratory in $0.9 \% \mathrm{NaCl}$ (w/v) containing $75 \mu \mathrm{g}$ potassium penicillin $\mathrm{G} / \mathrm{ml}$ and $50 \mu \mathrm{g}$ streptomycin sulphate $/ \mathrm{ml}$ at $37-39^{\circ} \mathrm{C}$ within $1 \mathrm{~h}$. Oocytes were aspirated through an 18-gauge needle into a disposable $1-\mathrm{ml}$ syringe from follicles $2-5 \mathrm{~mm}$ in diameter. The collected oocytes were washed 4 times with the maturation medium, TCM-199B supplemented with 10 iu pregnant mares' serum gonadotrophin/ml, 10 iu human chorionic gonadotrophin $/ \mathrm{ml}$ and $1 \mu \mathrm{g}$ oestradiol-17ß/ml $($ Sigma Chemical Co., St Louis, MO, USA). Ten oocytes with compact cumulus masses were transferred to a droplet of $100 \mu 1$ of maturation medium covered with warm paraffin oil in a polystyrene culture dish $(35 \times 10 \mathrm{~mm})$ and cultured for $36 \mathrm{~h}$ at $39^{\circ} \mathrm{C}$ in $5 \% \mathrm{CO}_{2}$ in air. In a preliminary experiment, of 78 oocytes with an expanded cumulus mass, 5 were still at the germinal vesicle stage, but $18(23 \%)$ and $55(71 \%)$ were at the stages of metaphase to telophase I and metaphase II, respectively. Since it was difficult to distinguish matured from immature oocytes without removing cumulus cells, cultured oocytes with an expanded cumulus mass were used for in-vitro fertilization. Five oocytes were washed twice and placed into $50 \mu \mathrm{l} \mathrm{TCM}-199 \mathrm{~B}$ with different concentrations of caffeine and sodium benzoate (Sigma Chemical Co.) and/or pig intestinal mucosal heparin (176 United States Pharmacopoeia units/ml: Sigma Chemical Co.), which had been covered with paraffin oil in a culture dish. The dishes were kept in a $\mathrm{CO}_{2}$ incubator $\left(5 \% \mathrm{CO}_{2}\right.$ in air at $\left.39^{\circ} \mathrm{C}\right)$ for $\sim 30$ min until spermatozoa were added for fertilization.

\section{Sperm preparation}

The sperm-rich portion of the ejaculated semen collected from boars by the glove method and filtering through double gauze was kept at $15^{\circ} \mathrm{C}$ for $2-3 \mathrm{~h}$. Semen samples were then diluted 1:2 with Hülsenberger VIII diluent (Richter et al., 1975) at $15^{\circ} \mathrm{C}$ and centrifuged for $15 \mathrm{~min}$ at $300 \mathrm{~g}$. The supernatant was discarded and spermatozoa were resuspended in Beltsville F5 extender (Pursel \& Johnson, 1975) to give $10 \times 10^{8}$ cells $/ \mathrm{ml}$. After cooling to $5^{\circ} \mathrm{C}$ over $1 \mathrm{~h}$, the sperm suspensions were diluted with the same volume of BF-5 solution containing $2 \%$ (v/v) glycerol. The sperm suspensions were frozen in $0.1 \mathrm{ml}$ pellets on solid $\mathrm{CO}_{2}$ and stored in liquid nitrogen until required for in-vitro fertilization. Frozen spermatozoa ( 8 pellets) were thawed in $2 \mathrm{ml} \mathrm{TCM}-199 \mathrm{~B}$ at $37^{\circ} \mathrm{C}$ for $\sim 1 \mathrm{~min}$. After thawing, 6-8 ml TCM-199B was added and spermatozoa were washed 3 times by centrifugation at $550 \mathrm{~g}$ for $5 \mathrm{~min}$ each time. The spermatozoa were resuspended in TCM-199B to give $2-200 \times 10^{6} \mathrm{cells} / \mathrm{ml}$. Before centrifugation (just after thawing) and after centrifugation (at insemination), the percentage of spermatozoa with progressive forward motility was examined under a phase-contrast microscope on a warm plate at $37^{\circ} \mathrm{C}$.

\section{In-vitro fertilization and examination of oocytes}

A 50- $\mu$ l sample of final sperm suspension was introduced into $50 \mu \mathrm{l}$ of TCM-199B with different concentrations of caffeine and/or heparin that included the oocytes.

At $14-16 \mathrm{~h}$ after insemination $\left(5 \% \mathrm{CO}_{2}\right.$ in air at $\left.39^{\circ} \mathrm{C}\right)$, oocytes were mounted, fixed for $48 \mathrm{~h}$ in $25 \%$ (v/v) acetic alcohol at room temperature, stained with $1 \%(\mathrm{w} / \mathrm{v})$ orcein in $45 \%(\mathrm{v} / \mathrm{v})$ acetic acid and examined under a phasecontrast microscope at a magnification of $\times 200$ or $\times 400$. Oocytes were considered as penetrated when they had a swollen sperm nucleus(ei) and/or a male pronucleus(ei) and corresponding sperm tail(s) in the cytoplasm. Oocytes with $>2$ pronuclei and a clear second polar body, even without a sperm tail, were also considered as penetrated.

Experiment 1. The effect of sperm concentration on in-vitro penetration of oocytes was examined using spermatozoa, obtained from boar D26, in TCM-199B containing $5 \mathrm{~mm}$ caffeine.

Experiment 2. The abilities of spermatozoa from 6 boars to penetrate oocytes in vitro were compared. The final concentrations of spermatozoa at fertilization were $25-50 \times 10^{6}$ cells $/ \mathrm{ml}$ in TCM-199B with $5 \mathrm{mM}$ caffeine.

Experiment 3. The effect of concentration of caffeine in TCM-199B on in-vitro penetration of oocytes was examined using spermatozoa from boar D26 at $25-50 \times 10^{6}$ cells $/ \mathrm{ml}$.

Experiment 4. It has been reported that in cattle caffeine and heparin have synergistic effects on inducing capacitation of frozen bull spermatozoa (Niwa \& Ohgoda, 1988); the possible occurrence of such an effect in fertilization of pig oocytes in vitro was investigated. Spermatozoa from boars D26 and W860 were used at $25-50 \times 10^{6}$ cells/ml.

\section{Results}

\section{Experiment 1}

Few oocytes were penetrated at sperm concentrations of $1-6 \times 10^{6}$ cells $/ \mathrm{ml}$ (Table 1 ), but high penetration rates $(85-89 \%)$ and an increased incidence of polyspermy were obtained with $>25 \times 10^{6}$ spermatozoa $/ \mathrm{ml}$. The proportions of penetrated oocytes with male and female pronuclei were low (11-38\%) and not correlated with sperm concentration. The mean number of penetrated spermatozoa per oocyte increased with increasing sperm concentration. 
Table 1. Penetration in vitro of pig oocytes by frozen-thawed ejaculated spermatozoa (from boar D26) at different sperm concentrations in the presence of $5 \mathrm{~mm}$ caffeine

\begin{tabular}{lccccccc}
\hline & & & \multicolumn{3}{c}{ No. of oocytes penetrated } & & No. of \\
\cline { 5 - 7 } $\begin{array}{l}\text { Sperm } \\
\text { concentration } \\
\left(\times 10^{-6} / \mathrm{ml}\right)\end{array}$ & $\begin{array}{c}\text { No. of } \\
\text { trials }\end{array}$ & $\begin{array}{c}\text { No. of } \\
\text { oocytes } \\
\text { examined }\end{array}$ & $\begin{array}{c}\text { Total } \\
(\%)\end{array}$ & $\begin{array}{c}\text { With } \\
\text { swollen } \\
\text { sperm head }\end{array}$ & $\begin{array}{c}\text { With male } \\
\text { and female } \\
\text { pronuclei }\end{array}$ & $\begin{array}{c}\text { Mean no. of } \\
\text { polyspermic } \\
\text { oocytes } \\
(\%)\end{array}$ & $\begin{array}{c}\text { Mpermatozoa } \\
\text { in penetrated } \\
\text { oocytes }\end{array}$ \\
\hline 1 & 6 & 88 & $0(0)$ & 0 & 0 & - & - \\
2 & 3 & 50 & $0(0)$ & 0 & 0 & - & - \\
3 & 5 & 75 & $3(4)$ & 2 & 1 & $0(0)$ & $1 \cdot 0$ \\
6 & 5 & 83 & $10(12)$ & 7 & 3 & $4(40)$ & $1 \cdot 6$ \\
12 & 5 & 79 & $34(43)$ & 21 & 13 & $18(53)$ & $2 \cdot 0$ \\
25 & 5 & 75 & $66(88)$ & 41 & 24 & $41(62)$ & $2 \cdot 3$ \\
50 & 4 & 53 & $45(85)$ & 40 & 5 & $30(67)$ & $2 \cdot 6$ \\
100 & 6 & 90 & $80(89)$ & 60 & 20 & $56(70)$ & $3 \cdot 1$ \\
\hline
\end{tabular}

\section{Experiment 2}

The percentages of motile spermatozoa at fertilization were low (5-20\%) in all boars used (Table 2). In general, the motility of spermatozoa not directly associated with the oocyte-cumulus complex in the medium decreased rapidly after insemination. Spermatozoa from boars D26, W860 and L612 showed similar motility (20\%), but differed greatly in penetration rate (19-89\%) of oocytes. The proportions of oocytes penetrated by spermatozoa from boars D1, D49 and D125, which had motilities of 10,10 and $5 \%$, respectively, were comparatively low.

Table 2. Penetration in vitro of pig oocytes by frozen-thawed ejaculated spermatozoa $\left(25-50 \times 10^{6} / \mathrm{ml}\right)$ obtained from 6 boars in the presence of $5 \mathrm{~mm}$ caffeine

\begin{tabular}{lccccccc}
\hline & & Percentage & & \multicolumn{3}{c}{ No. of oocytes penetrated } & \\
\cline { 5 - 6 } Boar & $\begin{array}{c}\text { No. of } \\
\text { trials }\end{array}$ & $\begin{array}{c}\text { of motile } \\
\text { spermatozoa at } \\
\text { fertilization }\end{array}$ & $\begin{array}{c}\text { No. of } \\
\text { oocytes } \\
\text { examined }\end{array}$ & $\begin{array}{c}\text { Total } \\
(\%)\end{array}$ & $\begin{array}{c}\text { With } \\
\text { swollen } \\
\text { sperm head }\end{array}$ & $\begin{array}{c}\text { With male } \\
\text { and female } \\
\text { pronuclei }\end{array}$ & $\begin{array}{c}\text { No. of } \\
\text { polyspermic } \\
\text { oocytes } \\
(\%)\end{array}$ \\
\hline D1 & 8 & 10 & 91 & $48(53)$ & 27 & 21 & $18(38)$ \\
D26 & 3 & 20 & 44 & $39(89)$ & 21 & 18 & $26(67)$ \\
D49 & 3 & 10 & 38 & $18(47)$ & 13 & 5 & $6(33)$ \\
D125 & 6 & 5 & 75 & $12(16)$ & 12 & 0 & $0(0)$ \\
W860 & 4 & 20 & 50 & $43(86)$ & 19 & 24 & $20(47)$ \\
L612 & 4 & 20 & 48 & $9(19)$ & 7 & 2 & $1(11)$ \\
\hline
\end{tabular}

\section{Experiment 3}

None of the oocytes was penetrated when caffeine was not included in the medium (Table 3). The highest proportion $(89 \%)$ of oocytes was penetrated with $5.0 \mathrm{~mm}$ caffeine $(P<0.05)$, but, at this caffeine concentration, incidence of polyspermy was also high $(67 \%)$.

\section{Experiment 4}

None of the oocytes was penetrated at any concentrations of heparin in the medium without caffeine (Table 4). With $5 \mathrm{~mm}$ caffeine in the medium, the proportion of oocytes penetrated decreased as the concentration of heparin increased; the penetration of oocytes was completely inhibited when the medium was supplemented with $40 \mu \mathrm{g}$ heparin $/ \mathrm{ml}$. 
Table 3. Effect of concentration of caffeine in the medium on penetration in vitro of pig oocytes by frozen-thawed ejaculated spermatozoa $\left(25-50 \times 10^{6} / \mathrm{ml}\right.$ from boar D26)

\begin{tabular}{|c|c|c|c|c|c|c|}
\hline \multirow[b]{2}{*}{$\begin{array}{l}\text { Concentration } \\
\text { of caffeine } \\
\text { (mM) }\end{array}$} & \multirow[b]{2}{*}{$\begin{array}{c}\text { No. of } \\
\text { trials }\end{array}$} & \multirow[b]{2}{*}{$\begin{array}{c}\text { No. of } \\
\text { oocytes } \\
\text { examined }\end{array}$} & \multicolumn{3}{|c|}{ No. of oocytes penetrated } & \multirow{2}{*}{$\begin{array}{l}\text { No. of } \\
\text { polyspermic } \\
\text { oocytes } \\
(\%)\end{array}$} \\
\hline & & & $\begin{array}{l}\text { Total } \\
(\%)\end{array}$ & $\begin{array}{c}\text { With } \\
\text { swollen } \\
\text { sperm head }\end{array}$ & $\begin{array}{l}\text { With male } \\
\text { and female } \\
\text { pronuclei }\end{array}$ & \\
\hline 0.0 & 3 & 41 & $0(0)$ & 0 & 0 & - \\
\hline $2 \cdot 5$ & 3 & 40 & $28(70)$ & 19 & 9 & $18(64)$ \\
\hline $5 \cdot 0$ & 3 & 44 & $39(89)^{*}$ & 21 & 18 & $26(67)$ \\
\hline $10 \cdot 0$ & 3 & 46 & $30(65)$ & 23 & 7 & $12(40)$ \\
\hline $20 \cdot 0$ & 3 & 42 & $4(9)$ & 4 & 0 & $0(0)$ \\
\hline
\end{tabular}

${ }^{*} P<0.05$ compared with the values at all other concentrations of caffeine $\left(\chi^{2}\right.$ test).

Table 4. Effect of heparin in the medium with or without caffeine on penetration in vitro of pig oocytes by frozen-thawed ejaculated spermatozoa $\left(25-50 \times 10^{6} / \mathrm{ml}\right)$

\begin{tabular}{|c|c|c|c|c|c|c|c|}
\hline \multirow{3}{*}{$\begin{array}{l}\text { Concentration } \\
\text { of heparin } \\
(\mu \mathrm{g} / \mathrm{ml})\end{array}$} & \multicolumn{4}{|c|}{ With caffeine (5mM)* } & \multicolumn{3}{|c|}{ Without caffeine $\dagger$} \\
\hline & \multirow[b]{2}{*}{$\begin{array}{c}\text { No. of } \\
\text { trials }\end{array}$} & \multicolumn{2}{|c|}{ No. of oocytes } & \multirow{2}{*}{$\begin{array}{c}\text { No. of } \\
\text { polyspermic } \\
\text { oocytes (\%) }\end{array}$} & \multirow[b]{2}{*}{$\begin{array}{l}\text { No. of } \\
\text { trials }\end{array}$} & \multicolumn{2}{|c|}{ No. of oocytes } \\
\hline & & Examined & $\underset{(\%)}{\text { Penetrated } \ddagger}$ & & & Examined & $\begin{array}{c}\text { Penetrated } \\
(\%)\end{array}$ \\
\hline 0 & $4 \S$ & 50 & $19+24(86)$ & $20(47)$ & 39 & 41 & $0(0)$ \\
\hline 5 & 3 & 35 & $9+13(63)$ & $10(46)$ & - & - & - \\
\hline 10 & 3 & 40 & $15+8(56)$ & $11(48)$ & 3 & 39 & $0(0)$ \\
\hline 20 & 3 & 46 & $9+7(35)$ & $3(19)$ & 3 & 49 & $0(0)$ \\
\hline 30 & 3 & 40 & $6+4(25)$ & $3(30)$ & 3 & 50 & $0(0)$ \\
\hline 40 & 3 & 41 & $0+0(0)$ & - & 3 & 52 & $0(0)$ \\
\hline
\end{tabular}

*Spermatozoa from boar W860.

$\dagger$ Spermatozoa from boar D26.

†The first figure denotes the number of oocytes with swollen sperm head(s); the second denotes the number with male and female pronuclei.

§Data from boar W860, Table 2.

ๆData from boar D26, Table 3.

\section{Discussion}

Nagai et al. (1988) reported that, in contrast to fresh ejaculated or frozen epididymal spermatozoa, no frozen ejaculated spermatozoa penetrated pig oocytes matured in culture. In their study, the spermatozoa were preincubated for $4 \mathrm{~h}$ before insemination, which resulted in great reduction of sperm motility. The reduced motility of frozen ejaculated spermatozoa after preincubation was also reported by Clarke \& Johnson (1987). Since, in the present study, percentages of sperm motility of frozen-thawed ejaculated spermatozoa from 6 boars were low (5-20\%), spermatozoa were used without preincubation for in-vitro fertilization of oocytes. Although further and rapid reduction of sperm motility was observed in spermatozoa not directly associated with the oocyte-cumulus complex, the present results clearly show that frozen ejaculated boar spermatozoa can penetrate oocytes matured in culture. This result may indicate that spermatozoa penetrating the cumulus mass before complete loss of motility can maintain their ability to undergo capacitation and to penetrate oocytes. The necessity of cumulus cells for frozen boar epididymal spermatozoa to complete capacitation is suggested by Nagai et al. (1988). 
The present results indicate that sperm concentrations at fertilization are important for penetration of oocytes with frozen ejaculated spermatozoa. High penetration rates $(85-89 \%)$ were obtained with spermatozoa from boars D26 and W860 at 25-100 $\times 10^{6}$ spermatozoa/ml (Tables 1 and 2), but these concentrations are not necessarily optimum for spermatozoa from other boars. For example, spermatozoa from boar L612 showed low penetrability (19\%). Such variation occurred regardless of sperm motility because the frozen ejaculated spermatozoa from these 3 boars showed the same percentage $(20 \%)$ of motility at fertilization. It is not clear whether the optimal sperm concentration for fertilization of oocytes or the ability of spermatozoa to penetrate oocytes differs among boars. On the other hand, if sperm concentration had been increased in frozen semen or samples from boars D1, D49 and D125, which showed less motility (5-10\%) and lower penetrability (16-53\%), penetration rates of oocytes might have increased, but this was not examined in the present study.

Several investigators have used medium supplemented with $2 \mathrm{~mm}$ caffeine for in-vitro fertilization of pig oocytes (Hamano \& Toyoda, 1986; Yoshida, 1987; Naito et al., 1988; Nagai et al., 1988; Hamano et al., 1989). It has been reported that caffeine enhances and prolongs motility of bull and boar spermatozoa (Garbers et al., 1971, 1973) and that the treatment of frozen-thawed bull spermatozoa with caffeine results in increasing penetration rates in vitro of oocytes (Niwa et al., 1988; Ohgoda et al., 1988). Fraser (1979) has reported that caffeine may accelerate the rate of sperm capacitation in mice. Since, in the present study, penetration rates of pig oocytes in vitro were dependent upon the concentration of caffeine supplemented to the medium (resulting in no penetration without caffeine and the highest penetration rate $(89 \%)$ at $5 \mathrm{~mm})$, it appears that caffeine has an essential role(s) for either inducing capacitation of spermatozoa or penetration of oocytes.

Heparin has been known to stimulate capacitation of bull spermatozoa in vitro (Parrish et al., 1988). The synergistic effect of caffeine and heparin in inducing capacitation of frozen-thawed bull spermatozoa, resulting in increased penetration rates in vitro of oocytes matured in culture, has also been reported (Niwa \& Ohgoda, 1988). In the present study, however, heparin did not support in-vitro penetration of pig oocytes with frozen ejaculated spermatozoa, but inhibited the efficacy of caffeine to promote penetration of oocytes. Although it is difficult to explain why species difference in heparin effects occur, different functions of heparin have been reported in hamsters, in which an acrosome reaction, rather than capacitation of spermatozoa, appears to be induced by heparin (Meizel \& Turner, 1986).

In the present study, the proportion of penetrated oocytes with male and female pronuclei were low $(0-59 \%)$ and the incidence of polyspermy was high. The poor formation of male pronuclei (Motlik \& Fulka, 1974; Nagai et al., 1984, 1988; Mattioli et al., 1988; Naito et al., 1988) and high incidence of polyspermy (Nagai et al., 1984; Cheng, 1985; Mattioli et al., 1988) in pig oocytes matured in culture have been repeatedly reported by many workers. Although abnormal formation of male pronuclei can result from incomplete maturation in vitro, it appears that the high incidence of polyspermy is not due entirely to abnormal maturation of oocytes, because pig oocytes matured in vivo are also penetrated by high numbers of spermatozoa after in-vitro fertilization (Cran \& Cheng, 1986). Since the requirements of follicle somatic cells (Mattioli et al., 1988; Moor et al., 1990) and pig follicular fluid (Naito et al., 1988) for normal in-vitro maturation of pig oocytes have recently been clarified, it is important to develop procedures that prevent polyspermy during in-vitro fertilization of pig oocytes (Nagai \& Moor, 1990).

We thank K. Bamba and Y. Nogami for preparation of frozen semen and T. Nagai for valuable advice.

\section{References}

Cheng, W.T.K. (1985) In vitro fertilization of farm animal oocytes. Ph.D. thesis. Council for National Academic Awards.
Clarke, R.N. \& Johnson, L.A. (1987) Effect of liquid storage and cryopreservation of boar spermatozoa on acrosomal integrity and the penetration of 
zona-free hamster ova in vitro. Gamete Res. 16, 193-204.

Cran, D.G. \& Cheng, W.T.K. (1986) The cortical reaction of pig oocytes during in vivo and in vitro fertilization. Gamete Res. 13, 241-251.

Fraser, L.R. (1979) Accelerated mouse sperm penetration in vitro in the presence of caffeine. J. Reprod. Fert. 57, 377-384.

Garbers, D.L., First, N.L., Sullivan, J.J. \& Lardy, H.A. (1971) Stimulation and maintenance of ejaculated bovine spermatozoan respiration and motility by caffeine. Biol. Reprod. 5, 336-339.

Garbers, D.L., First, N.L., Gorman, S.K. \& Lardy, H.A. (1973) The effects of cyclic nucleotide phosphodiesterase inhibitors on ejaculated porcine spermatozoa metabolism. Biol. Reprod. 8, 599-606.

Hamano, S. \& Toyoda, Y. (1986) In vitro fertilization of pig eggs with ejaculated spermatozoa preincubated at high sperm concentration. Jap. J. Anim. Reprod. 32, 177-183.

Hamano, S., Naito, K., Fukuda, Y. \& Toyoda, Y. (1989) In vitro capacitation of boar ejaculated spermatozoa: effect of conditioned media prepared from preincubated sperm suspension. Gamete Res. 24, 483-489.

Iritani, A., Niwa, K. \& Imami, H. (1978) Sperm penetration in vitro of pig follicular oocytes matured in culture. J. Reprod. Fert. 54, 379-383.

Mattioli, M., Galeati, G. \& Seren, E. (1988) Effect of follicle somatic cells during pig oocyte maturation on egg penetrability and male pronucleus formation. Gamete Res. 20, 177-183.

Mattioli, M., Bacci, M. L., Galeati, G. \& Seren, E. (1989) Developmental competence of pig oocytes matured and fertilized in vitro. Theriogenology 31, 1201-1207.

Meizel, S. \& Turner, K. O. (1986) Glycosaminoglycans stimulate the acrosome reaction of previously capacitated hamster sperm. J. exp. Zool. 237, 137-139.

Moor, R. M., Mattioli, M., Ding, J. \& Nagai, T. (1990) Maturation of pig oocytes in vivo and in vitro. $J$. Reprod. Fert. Suppl. 40, 197-210.

Motlik, J. \& Fulka, J. (1974) Fertilization of pig follicular oocytes cultivated in vitro. J. Reprod. Fert. 36, 235-237.

Nagai, T. \& Moor, R. N. (1990) Effect of oviduct cells on the incidence of polyspermy in pig oocytes fertilized in vitro. Mol. Reprod. Dev. 26, 377-382.

Nagai, T., Niwa, K. \& Iritani, A. (1984) Effect of sperm concentration during preincubation in a defined medium on fertilization in vitro of pig follicular oocytes. J. Reprod. Fert. 70, 271-275.

Nagai, T., Takahashi, T., Masuda, H., Shioya, Y., Kuwayama, M., Fukushima, M., Iwasaki, S. \& Hanada, A. (1988) In-vitro fertilization of pig oocytes by frozen boar spermatozoa. J. Reprod. Fert. 84, 585-591.

Nagai, T., Takahashi, T., Shioya, Y. \& Oguri, N. (1990) Maturation and fertilization of pig follicular oocytes cultured in pig amniotic fluid. Theriogenology 34, 195-204.

Naito, K., Fukuda, Y. \& Toyoda, Y. (1988) Effects of porcine follicular fluid on male pronucleus formation in porcine oocytes matured in vitro. Gamete Res. 21, 289-295.

Niwa, K. \& Ohgoda, O. (1988) Synergistic effect of caffeine and heparin on in vitro fertilization of cattle oocytes matured in culture. Theriogenology 30, 733 741 .

Niwa, K., Ohgoda, O. \& Yuhara, M. (1988) Effects of caffeine in media for pretreatment of frozen-thawed sperm on in-vitro penetration of cattle oocytes. Proc. Ilth Int. Congr. Anim. Reprod. \& A.I., Dublin 3, abstr. 346 (3 pp).

Ohgoda, O., Niwa, K., Yuhara, M., Takahashi, S. \& Kanoya, K. (1988) Variations in penetration rates in vitro of bovine follicular oocytes do not reflect conception rates after artificial insemination using frozen semen from different bulls. Theriogenology 29, 1375-1381.

Parrish, J.J., Susko-Parrish, J., Winer, M.A. \& First, N.L. (1988) Capacitation of bovine sperm by heparin. Biol. Reprod. 38, 1171-1180.

Pursel, V.G. \& Johnson, L.A. (1975) Freezing of boar spermatozoa: fertilizing capacity with concentrated semen and a new thawing procedure. J. Anim. Sci.40, 99-102.

Richter, L., Romeny, E., Weitze, K.F. \& Zimmermann, F. (1975) Deep freezing of boar semen. VII. Communication: Laboratory and field experiments using the extender Hülsenberg VIII. Dt. tierärztl. Wschr. 82, 155-162.

Yoshida, M. (1987) In vitro fertilization of pig oocytes matured in vitro. Jap. J. vet. Sci. 49, 711-718.

Yoshida, M., Ishizaki, Y. \& Kawagishi, H. (1990) Blastocyst formation by pig embryos resulting from in-vitro fertilization of oocytes matured in vitro. $J$. Reprod. Fert. 88, 1-8.

Received 10 December 1990 